9. Novikova, L. I. (2000). Vospitanie kak pedagogicheskaja kategorija [Education as a pedagogical category]. Pedagogika. 6, $32-33$ [in Russian].

10. Novyi tlumachnyi slovnyk ukrainskoi movy [New interpretative dictionary of the Ukrainian language] (2003) / uklad. V. V. Yaremenko, O. M. Slipushko. Kyiv. 926 p. [in Ukrainian].

11. Pryshchepa, S. M. (2017). Osoblyvosti proektuvannia vykhovnoi systemy zahalnoosvitnoho navchalnoho zakladu [Features of designing educational system of a comprehensive educational institution]. Naukovi zapysky Kirovohradskoho derzhavnoho pedahohichnoho universytetu imeni Volodymyra Vynnychenka. 150. 94-97. [in Ukrainian].

12. Providnytstvo v osviti. Vid idei do vichnosti [From idea to eternity]: kolektyvna monohrafiia (2017) / za zah. red. I. T. Bohdanova. K.: Osvita Ukrainy, 368 p. [in Ukrainian].

13. Prohrama «Nova ukrainska shkola» u postupi do tsinnostei [The New Ukrainian School program is in the process of moving towards values] (2018). Kyiv [in Ukrainian].

14. Soroka, H. I. (2002). Suchasni vykhovni systemy ta tekhnolohii: posibnyk [Modern educational systems and technologies: a guide]. Xarkiv, 128 p. [in Ukrainian].

15. Stepanov, E. N. (2008). Pedagogu o vospitatel'noj sisteme shkoly i klassa [Teacher about the educational system of school and class]. Moskva, 224 p. [in Russian].

\title{
Haharin M. I. Modern approaches to the design of the educational system of the general secondary education
}

The article analyzes modern approaches to designing the educational system of a general secondary education institution; the views of scientists on the potential and features of pedagogical design are considered.

The purpose of the article is to identify and analyze modern approaches to designing the educational system of a general secondary education institution. The article covers the essence of the concept of «system», "educational system»; designing the educational system of a general secondary education institution is interpreted as the purposeful determination of the program of life of the subjects of pedagogical interaction, all components of which are interconnected, form a coherent structure and ensure the achievement of the defined goals and objectives of education.

The educational system of a general secondary education institution is defined as a complex of interrelated and interdependent basic components (educational goal, concept, tasks, subjects (pupils, teachers, parents), living space (system-forming activity, communication, relations, management, self-government, interaction), which is a complete socio-pedagogical structure and provides in the process of its functioning and development of formation, realization and self-realization of the individual, his life realization in the physical, mental, social and spiritual and spheres.

Factors that determine the specific design of the educational system of a particular educational institution include the system of values of the institution of general secondary education, its structure and life; socio-psychological climate, organizational culture, staffing potential, features of the student contingent; availability of resources; the impact of the environment.

The modern approaches to the design of the educational system (axiological, personality-developmental, systemic, deterministic, synergistic, formative, paradigmatic) are distinguished and characterized; making it possible to create and operate effective educational systems in general secondary education institutions.

The research materials can be used in the process of designing and developing the educational system of a general secondary education institution at the present stage.

Key words: system, educational system, educational system of general secondary education institution, project, designing, pedagogical design, project of educational system, approaches to design of educational system.

УДК 377.36:37.091.33:808.5

DOI https://doi.org/10.31392/NPU-nc.series5.2020.72-1.26

Гилярська O.I.

\section{МЕТОДОЛОГІЧНІ ПІДХОДИ ДО ФОРМУВАННЯ ПРОФЕСІЙНО ОРІЄНТОВАНОЇ РИТОРИЧНОЇ КОМПЕТЕНТНОСТІ МАЙБУТНІХ ВЧИТЕЛІВ У ПЕДАГОГІЧНИХ КОЛЕДЖАХ: ШЛЯХИ РЕАЛІЗАЦІї}

Розглядаються методологічні підходи до формування професійно орієнтованої риторичної компетентності майбутніх вчителів у навчальному процесі в педагогічних коледжах. Здійснено огляд наукових джерел щодо аналізу таких методологічних підходів, як компетентнісний, особистісно орієнтований, діяльнісний та задачний. 3'ясовано, щзо з позицій цих підходів найбільш логічно розглядати формування професійно орієнтованої риторичної компетентності.

Визначено, щзо відповідно до компетентнісного підходу процес навчання набуває розвивального характеру $i$ містить знання, вміння, навички, ставлення та досвід педагогічної діяльності. Доведено, що особистісно орієнтований підхід спрямований на визнання цінності, унікальності, неповторності особистості майбутнього вчителя, його права на вільний розвиток та прояв своїх здібностей у педагогічній діяльності, формування власного стилю у спілкуванні. Зазначається, щуо діяльнісний підхід реалізується під час иілеспрямованого навчання та процесу виховання, яке здійснюється в результаті використання переконливого слова. Акиентовано увагу на тому, щчо задачний підхід формування професійно орієнтованої риторичної компетентності в майбутніх учителів є процесом формування здатності розв'язувати професійно-комунікативні задачі.

Наголошується на важливості риторичної компетентності для педагога, оскільки вона має професійне спрямування та застосовується насамперед для розв'язання навчально-виховних завдань. Доведено, щяо професійно орієн- 
тована риторична компетентність майбутнього вчителя пов'язана з майстерністю педагогічного впливу словом, з дієвістю технології розвивального культуровідповідного навчання та виховання за допомогою ефективного, переконливого мовлення. Визначено перспективи подальших досліджень у даному напрямі.

Ключові слова: методологічні підходи, професійно орієнтована риторична компетентність, майбутні вчителі, компетентнісний підхід, особистісно орієнтований підхід, діяльнісний підхід, задачний підхід, педагогічні коледжі.

Відповідно до запитів сучасного суспільства й освіти майбутній педагог повинен володіти риторичною компетентністю. Формування риторичної компетентності, яка $€$ важливим компонентом у структурі загального розвитку й професійної підготовки майбутнього педагога, має бути пріоритетним упродовж усього професійно орієнтованого навчання в закладах освіти, а особливо на межі школи і педагогічного коледжу, де вона актуалізується відповідно до вікових особливостей психофізіологічного розвитку студентів і загальнодидактичних принципів наступності й перспективності навчання.

У контексті нашого дослідження виявлено, що концепції гуманізації та гуманітаризації освіти приділяли увагу такі науковці, як В. Андрущенко, С. Гончаренко, В. Кремень, В. Огнев’юк та ін. Теоретичним ідеям щодо особливостей змісту й процесу професійної підготовки майбутніх педагогів присвятили дослідження А. Алексюк, С. Вітвицька, О. Дубасенюк, Н. Ничкало, О. Пєхота В. Сластьонін, Л. Хомич та ін. Теоретичні узагальнення про компетентнісний підхід до навчання здійснили Н. Бібік, В. Химинець, О. Овчарук, I. Пометун та ін. Проте проблема формування професійно орієнтованої риторичної компетентності на засадах компетентнісного, особистісно орієнтованого, діяльнісного та задачного підходах вивчена недостатньо.

Мета статті - обгрунтувати найбільш логічні методологічні підходи до формування професійно орієнтованої риторичної компетентності майбутніх вчителів у навчальному процесі в педагогічних коледжах.

Надзвичайно важливу роль у нашому дослідженні професійно орієнтованої риторичної компетентності відіграє підхід, що означає певну позицію стосовно проблеми, яку ми досліджуємо. За О. Дубасенюк, підхід - це теоретичне або логічне підгрунтя розгляду або проектування об'єкта; сукупність способів і прийомів здійснення діяльності на основі будь-якої ідеї або принципу [5, с. 65].

У законі України «Про освіту» проголошено курс на впровадження компетентнісного підходу до освіти. Досягнення цієї мети забезпечується формуванням ключових компетентностей, які є необхідними кожній сучасній людині для успішної життєдіяльності. Компетентнісний підхід передбачає не лише демонстрацію знань, умінь і навичок від майбутнього фахівця, а формування в нього професійної компетентності. Реалізація такого підходу передбачає використання відповідних освітніх технологій у навчанні, рефлексію студентів, самостійність застосування професійних умінь і навичок у педагогічній діяльності.

Компетентнісний підхід, як вважає К. Рудніцька, переміщує акценти з процесу накопичення нормативно визначених знань, умінь і навичок майбутніх фахівців у площину формування і розвитку здатності практично діяти і творчо застосовувати набуті знання і досвід у різних ситуаціях. Це вимагає від викладача змістити акценти у своїй навчально-виховній діяльності з інформаційної до організаційно-управлінської площини $[9,241]$. Відповідно до компетентнісного підходу викладач виступає організатором навчальновиховного процесу, а студент переходить від пасивного засвоєння знань до дослідницької активної, самостійної та самоосвітньої діяльності. Процес навчання набуває розвивального характеру і містить знання, вміння, навички, ставлення та досвід педагогічної діяльності.

Сучасні концепції педагогічної освіти, як стверджує О. Часнікова, базуються на ідеях розвитку людських ресурсів та саморозвитку освітніх інституцій і суб'єктів педагогічного процесу. Серед принципів професійного розвитку педагогів провідним визначає науковець реалізацію компетентнісного підходу до розвитку фахової кваліфікації педагогів, що передбачає необхідність переходу від кваліфікації, яку спеціаліст здобуває один раз і назавжди, до компетентності, яка дозволяє мобільно змінювати професійну діяльність, зумовлену соціально-економічними змінами, динамікою ринку праці [10]. Тому сьогодні студенти педагогічних коледжів набувають такі компетентності під час навчання, які будуть потрібні їм упродовж їхнього життя. Ці компетентності виявляються і використовуються на різних етапах становлення особистості, у професійних і соціальних аспектах іï життя.

Сутність компетентнісного підходу, як вважає О. Красільнікова, полягає не стільки в інформуванні людини, що навчається, скільки в здатності навчити їі вирішувати проблеми, які можуть виникнути як у професійному, так і в повсякденному житті. Тому важливим завданням сучасної освіти $€$ формування в майбутніх фахівців здатності самостійно вирішувати проблеми різної складності на основі отриманих знань та власного досвіду, а також критично мислити, уміти адаптуватися до умов мінливого світу. А цьому сприяе поєднання навчального процесу з професійною практикою [7]. Студенти педагогічних коледжів мають практику в навчально-виховних закладах освіти вже з другого курсу. Спочатку вони мають можливість ознайомитися з майбутньою професією, лише спостерігаючи за навчально-виховним процесом. I тільки після вивчення необхідних методик роботи студенти проводять заняття та виховні заходи самостійно. Таким чином, студенти педагогічних коледжів навчаються вирішувати проблеми різної складності на основі отриманих знань та власного досвіду.

Компетентнісний підхід, переконана О. Дубасенюк, спрямований на професійну компетентність як якість особистості майбутнього педагога / фахівця, що характеризує рівень його інтеграції як у середовище профе- 
сійної діяльності, так і в різні соціальні середовища, входження в які передбачає виконання різних соціальних ролей [5, с. 107]. Сьогодні майбутній педагог має володіти кількома компетентностями. Однією 3 провідних $є$ професійно орієнтована риторична компетентність майбутнього вчителя. Згідно з запитами сучасної освіти та суспільства майбутній педагог повинен конструктивно і системно мислити, креативно виражати своє ставлення до світу, поважати думку інших та бути готовим до гармонійної мовленнєвої взаємодії. Тому наявність у майбутніх педагогів риторичної компетентності, яка є обов'язковим компонентом педагогічної майстерності, є однією з умов розв'язання цього завдання. Володіючи риторичною компетентністю, майбутній педагог зможе виявити себе переконливим мовцем і досягти успіхів у педагогічній діяльності.

Педагогічні коледжі покликані розвивати в майбутніх учителів творче мислення, унікальні здібності, готовність до вибору, комунікабельність, суб'єктність, адаптованість, мобільність, толерантність, конкурентоспроможність та готовність до педагогічної діяльності. Реалізація компетентнісного підходу сприяє розвитку здібностей студентів педагогічних коледжів діяти в проблемних, нестандартних ситуаціях, шукати свій спосіб рішення, виробляти неповторний індивідуальний стиль педагогічної діяльності. Професійно орієнтована риторична компетентність є сьогодні провідною компетентністю для майбутнього педагога. Працівник освітнього галузі, який володіє риторичною компетентністю, здатний не лише ефективно виражати власні думки, але й стимулювати суб'єктів освітнього процесу до критичного мислення, творчого діалогу в процесі педагогічного дискурсу.

Тому ми вважаємо, що реалізацію компетентнісного підходу слід втілювати через систему завдань, практичних робіт, вправ і практик, які вимагають застосування різноманітних знань і умінь у різних навчальних і педагогічних ситуаціях. Крім того, використання проектних методик навчання вимагає від студентів високого рівня самостійності; у свою чергу різноманітні проблемні ситуації розвивають ініціативу, пошукові вміння та здібності майбутніх вчителів. Компетентнісний підхід орієнтується на цілісність і завершеність у підготовці студентів до майбутньої педагогічної діяльності.

Сьогодні одним з пріоритетів державної політики розвитку освіти є особистісна орієнтація навчання. Особистісно орієнтований підхід реалізується через побудову відкритої особистісної взаємодії в процесі навчання, у результаті чого створюються умови для особистісного розвитку та розкриваються здібності студентів, а процес навчання є засобом, що створює умови для виявлення та реалізації особистісних якостей студентів.

Особистісно орієнтований підхід вивчався такими науковцями, як С. Вітвицька, О. Дубасенюк, С. Яценко та ін. Науковці дотримуються думки, що особистісна орієнтація освіти сьогодні є надзвичайно важливою, оскільки вона спрямована на визнання цінності, унікальності та неповторності особистості майбутнього вчителя.

Як стверджує С. Яценко, особистісна орієнтація освіти висуває найбільш інтегративний, найбільш важливий критерій прогресу людства - рівень гуманізації суспільства, тобто саме становище в ньому особистості, яке визначає рівень їі економічної, політичної і соціальної свободи; рівень задоволення матеріальних і духовних потреб; стадії психофізичного і соціального здоров'я $[11,234]$. Таким чином, особистісно орієнтоване навчання реалізується лише в процесі суб'єкт-суб'єктної взаємодії головних учасників навчально-виховного процесу, викладача і студента, яке здійснюється при врахуванні психолого-педагогічних та методичних умовах навчання. До психолого-педагогічних умов науковець відносить психологічні основи організації особистісно орієнтованого навчання та підготовку вчителя/викладача до впровадження особисто орієнтованих технологій. Щодо методичних умов, то вони повинні гармонізувати освітні запити, цілі, прагнення учня/ студента та вчителя / викладача з їхніми потенційними можливостями.

Згідно з особистісно орієнтованим підходом навчання вчитель / викладач є одним з головних суб'єктів навчально-виховного процесу, орієнтація на людину як неповторну, унікальну особистість у системі особистісного орієнтованого навчання. Створення умов для саморозвитку студента, його самовиховання та самоорганізації потребує духовних контактів між студентом і викладачем та взаємно відповідального ставлення до спільної справи. Тому заохочення та підтримка природного бажання студента займатися учінням вимагає від викладача глибокого вивчення потреб студента, його соціальних та особистісних запитів, природних нахилів, індивідуальних особливостей, творчого потенціалу тощо.

За О. Дубасенюк, особистісно орієнтований підхід у професійно-педагогічній підготовці майбутнього вчителя передбачає орієнтацію освітнього процесу на загальну мету - розвиток особистості педагога. Це процес утвердження особистості як вищої цінності буття за умови пробудження в особистості потреби в самореалізації й самовдосконаленні $[5$, с. 78]. У результаті цього майбутній педагог є доброзичливим, позитивно ставиться до оточуючих людей та світу. Особистісно орієнтований підхід у підготовці майбутнього вчителя утворює підгрунтя для розвитку самоповаги, почуття власної гідності та поваги до інших особистостей.

Особистісно орієнтований навчально-виховний процес, на думку С. Вітвицької, будується не просто на врахуванні індивідуальних особливостей вихованців, а насамперед на послідовному завжди і у всьому ставленні до них як до особистостей, як до відповідальних і свідомих суб'єктів діяльності [3, с. 69]. Таким чином, визнання викладачем індивідуальності майбутнього педагога, врахування іiі в організації та здійсненні навчальної діяльності повинна проявитися в самій стратегії особистісно-орієнтованого навчання. 
Тому викладач підбирає різноманітні форми в педагогічному процесі, щоб найбільш ефективніше вплинути на особистість, у результаті чого відбувається ефективний розвиток особистості студента.

Діяльнісний підхід орієнтує навчально-виховний процес безпосередньо на особистості студентів, урахування їхніх індивідуальних особливостей та особистісного досвіду. Реалізація цього підходу потребує переведення студентів на позицію суб'єктів пізнання, оскільки діяльність є основним чинником становлення людини як особистості і професіонала. Питання діяльнісного підходу були предметом вивчення таких дослідників, як Л. Виготський, О. Дубасенюк, Т. Мартинюк та ін.

Так, наприклад, великим внеском Л. Виготського є розробка проблеми співвідношення навчання та розвитку дитини. Науковець ввів поняття зони актуального розвитку та зон найближчого розвитку. Л. Виготський стверджує, що зона найближчого розвитку має більше значення для динаміки інтелектуального розвитку і успішності навчання, ніж актуальний рівень їхнього розвитку [4, с. 247]. Дослідник додає, що в співпраці, під керівництвом, з чиєюсь допомогою учень / студент може зробити набагато більше і розв'язати більш складні задачі, ніж зробить це самостійно. Зона найближчого розвитку має найбільше значення для прогнозування динаміки та ефективності інтелектуального зростання. Саме ця зона визначає можливості навчання. Сьогодні навчання розглядається як найбільш вагомий чинник, складовий елемент соціальних впливів на психічний розвиток студента педагогічного коледжу. За умови цілеспрямованої організації навчання в педагогічному коледжі студент може досягнути найбільших висот свого розвитку та оволодіти необхідними компетентностями для успішного здійснення педагогічної діяльності.

Загальною характеристикою живих істот, за Т. Мартинюк, $є$ їх активність. Саме активність забезпечує підтримку життєво важливих зав'язків усіх істот з навколишнім світом. Джерелом активності живих організмів $є$ потреби, завдяки яким усе живе діє певним чином та в певному напрямі. Активність людини зумовлена потребами, які формуються в суспільстві в процесі навчання і виховання [8, с. 49]. Сучасний студент педагогічного коледжу потребує певний ряд компетентностей, які необхідні йому для здійснення майбутньої успішної педагогічної діяльності. Тому програми педагогічних коледжів складені так, щоб залучити студента до гармонійно організованої навчальної діяльності в коледжі, у результаті якої студент оволодіває необхідними компетентностями для майбутньої професії.

Майбутньому педагогу, як стверджує О. Дубасенюк, слід засвоїти важливе положення, що діяльність $є$ одним 3 основних чинників становлення людини як особистості і професіонала. Особистість пізнається в діяльності, а особистісна якість розвивається і формується в діяльності [5, с. 95]. Таким чином, діяльність для майбутнього педагога $є$ основними чинниками його становлення як особистості та професіоналу. Студент педагогічного коледжу розвивається або формується як особистість протягом чотирирічного навчання. Він постійно залучений до навчально-виховного процесу в коледжі, де створюється невимушена творча атмосфера під час взаємодії, формування системи цінностей у сфері міжособистісного та професійного спілкування. Це не лише стимулює розвиток особистості, свободу вибору, самостійність, незалежність дій, а й формує відповідальність за прийняті рішення.

Діяльнісний підхід відіграє важливу роль у підготовці майбутніх педагогів, оскільки специфіка навчальної діяльності полягає в спрямуванні на розвиток і саморозвиток суб'єкта цієї діяльності. Діяльнісний підхід передбачає, що в центрі навчання знаходиться особистість, іiі мотиви, цілі, неповторний іiі досвід.

Отже, діяльнісний підхід реалізується під час цілеспрямованого навчання та процесу виховання, яке здійснюється за допомогою переконливого слова. Професійно орієнтована риторична компетентність формується в результаті комунікативної діяльності, яка є складною системою взаємодії викладача і студента. Формування цієї компетентності вимагає організацію в навчально-виховному середовищі комунікативної діяльності, яка містить необхідну і достатню систему комунікативних знань і забезпечує їх застосування на практиці під час педагогічного спілкування зі всіма суб’єктами навчального процесу.

Сучасні навчальні заклади сьогодні потребують педагога, який вміє системно мислити, швидко і нестандартно розв'язувати проблеми, що виникають, та володіє високим рівнем розвитку творчого потенціалу. Розвиток творчого мислення студентів у процесі навчання входить до числа пріоритетних завдань, що стоять перед педагогічними коледжами. Творче мислення визначається, як таке, у результаті якого студент успішно розв'язує нову задачу, яка раніше ніколи ним не розв'язувалася, причому ця задача позв'язується незвичним, оригінальним способом, яким студент раніше не користувався. Задачний підхід вивчали Г. Балл, Л. Буркова, О. Дубасенюк та ін.

Так, задачі, за Г. Баллом, - це система, обов'язковими компонентами якої $є$ а) предмет задачі, що знаходиться у вихідному стані (тобто вихідний предмет задачі); б) модель, яка вимагає стану предмету задачі (тобто вимога задачі) [1, с. 32]. Способом рішення задачі науковець вважає будь-яку процедуру, яка при їі здійсненні може забезпечити рішення цієї задачі [1, с. 36]. Тому, говорячи про спосіб рішення задачі, необхідно враховувати характеристики вирішувача.

Г. Балл додає, що з поняттям способу рішення тісно пов'язане поняття процесу рішення задачі. Процес рішення задачі, за Г. Баллом, визначається як фрагмент функціонування вирішувача, який здійснюється особою в процесі рішення або з метою іiї вирішення. При цьому враховуються не лише виконувачі операції, а також тимчасові та енергетичні затрати на їхне здійснення [1, с. 39]. Студенти педагогічних коледжів вирішують багато задач щодня на заняттях з педагогіки, психології, фізіології, історії, української та іноземної мов. 
Дослідник співвідносить комунікативні задачі з пізнавальними. Предмет комунікативної задачі, як і пізнавальної, визначає затребуване вдосконалення знань. Відмінність цих задач полягає в тому, що в процесі рішення пізнавальної задачі особа вдосконалює знання, якими сама володіє; вирішуючи комунікативну задачу, особа вдосконалює знання, якими володіє друга активна система - реципієнт [1, с. 87]. Звичайно, для розвитку професійно орієнтованої риторичної компетентності вагоме значення має вирішення комунікативної задач, у процесі якого активізуються не тільки мовленнєві, але й пізнавальні процеси. Вирішуючи такі задачі, викладач педагогічного коледжу спонукає студента манерою висловлювання вплинути на слухача, зацікавити його чи переконати, тобто виявити себе переконливим мовцем.

Задачний підхід, як зазначає О. Дубасенюк, дає можливість посилити проблемну подачу навчального матеріалу під час лекційного викладу матеріалу, спонукає студентів до роздумів, творчого пошуку інформації, до самостійних висновків, узагальнень. Дослідниця додає, що проблемні питання та проблемні практичні завдання сприяють також розвитку рефлексії, самосвідомості, самооцінки майбутніх учителів [6, с. 160]. Цілком погоджуємося з іiі узагальненнями та висновками. Підбираючи педагогічні задачі до навчального матеріалу, викладач спирається на особистий досвід студентів, який набутий під час різних видів педагогічних практик, спонукає до вираження власної оцінки і таким чином стимулює формування гуманістично спрямованої позиції та ціннісних орієнтацій у майбутніх вчителів.

Серед продуктивних засобів розвитку мислення майбутніх вчителів О. Дубасенюк було виділено професійно-орієнтовані педагогічні задачі - спеціально відібрані задачі, які складені на основі типових педагогічних ситуацій, що виникають у реальній педагогічній дійсності і які вимагають від майбутніх педагогів застосування набутих психолого-педагогічних знань, урахування соціального замовлення суспільства, сучасних методологічних підходів, концептуальних ідей, зручних інноваційних засобів та методів 3 метою отримання продуктивного результату [6, с. 160]. Таким чином, майбутній педагог щодня 3 великою кількістю професійно-життєвих ситуацій, які вимагають від нього швидкого та кваліфікованого вирішення.

До того ж, заданий підхід, як стверджує Л. Буркова, у підготовці фахівців утворює можливість більш продуктивно готувати їх до майбутньої професійної діяльності. Розв' язуючи професійні задачі під час навчальної діяльності, майбутній фахівець вчиться поєднувати теоретичні знання з практичним їх застосуванням, бачити проблеми, трансформувати їх на задачі, ідентифікувати їх за рівнем складності, динаміки, ступенем визначеності, розуміти свій потенціал для їх розв’язування, шукати найкращі альтернативи розв'язку і отримувати гарантовано продуктивний результат [2, с. 11]. Студенти педагогічних коледжів мають цілий перелік предметів, на заняттях яких вони розв'язують професійні задачі, де демонструють свої теоретичні знання та вміння практично їх використовувати. Розв’язуючи такі задачі, майбутні педагоги наближаються до професійної діяльності, тобто до вирішення багатьох задач у майбутній педагогічній діяльності.

Отже, формування професійно орієнтованої риторичної компетентності майбутніх вчителів доцільно здійснювати засобами розв'язання комунікативних задач, тому педагогічною умовою формування професійно орієнтованої риторичної компетентності нами визначено розробку комплексу комунікативних задач, що сприятиме формуванню всіх складових професійно орієнтованої риторичної компетентності майбутнього педагога.

Формування професійно орієнтованої риторичної компетентності в майбутніх учителів на засадах задачного підходу є процесом формування здатності розв'язувати професійно-комунікативні задачі, які базуються на комунікативних знаннях та вміннях. Особливістю комунікативних задач $\epsilon$ те, що вони $\epsilon$ практико-зорієнтовані та їх розв’язання вимагає теоретичних предметних знань від студентів. Тому, щоб розв'язати такі задачі, студенти педагогічних коледжів повинні застосувати набуті теоретичні знання та власний комунікативний досвід.

Висновки. Таким чином, теоретичне підгрунтя розгляду формування професійно орієнтованої риторичної компетентності в майбутніх учителів у педагогічних коледжах базується на таких методологічних підходах, як компетентнісний, особистісно орієнтований, діяльнісний та задачний підходах. 3 позицій цих підходів найбільш логічно розглядати формування професійно орієнтованої риторичної компетентності. Відповідно до компетентнісного підходу процес навчання набуває розвивального характеру і містить знання, вміння, навички, ставлення та досвід педагогічної діяльності. Особистісно орієнтований підхід спрямований на визнання цінності, унікальності, неповторності особистості майбутнього вчителя, його права на вільний розвиток та прояв своїх здібностей у педагогічній діяльності, формування власного стилю у спілкуванні. Діяльнісний підхід реалізується під час цілеспрямованого навчання та процесу виховання, яке здійснюється в результаті використання переконливого слова. Задачний підхід формування професійно орієнтованої риторичної компетентності в майбутніх учителів є процесом формування здатності розв'язувати професійнокомунікативні задачі. Риторична компетентність педагога має професійне спрямування, вона застосовується насамперед для розв'язання навчально-виховних завдань. Проблема риторичної компетентності педагога актуальна вже тому, що пов'язана з майстерністю педагогічного впливу словом, 3 дієвістю технології розвивального культуровідповідного навчання та виховання за допомогою ефективного, переконливого мовлення. Перспективу подальшого дослідження ми вбачаємо у розробці моделі формування професійно орієнтованої риторичної компетентності в майбутніх учителів у педагогічних коледжах. 


\section{Використана література:}

1. Балл Г. А. Теория учебных задач: Психолого-педагогический аспект. Москва : Педагогика, 1990. 184 с.

2. Буркова Л.В. Задачний підхід у підготовці фахівців соціономічних професій: типи задач та особливості їх розв'язання. Вісник Киїського національного університету імені Тараса Шевченка. Педагогіка. 2015. Вип. 2. C. 11-16. URL: http://nbuv.gov.ua/UJRN/vknutshp 201524 (дата звернення: 10.01.2020).

3. Вітвицька С. С. Особистісно орієнтоване виховання студентів у вищих навчальних закладах освіти. Професійна педагогічна освіта: особистісно орієнтований підхід: монографія / за ред. О. А. Дубасенюк. Житомир: Вид-во ЖДУ імені I. Франка, 2012. С. 50-78.

4. Выготский Л. С. Собрание сочинений. В 6 т. Т. 2. Проблемы общей психологии / под ред. В. В. Давыдова. Москва : Педагогика, 1982. 504 с.

5. Дубасенюк О. А. Методологія та методи науково-педагогічного дослідження: навч.-методичний посібник. Вид. 2-ге допов. Житомир: ФО-П Левковець Н. М., 2019. 300 с.

6. Дубасенюк О. А. Реалізація задачного підходу у професійній підготовці майбутнього вчителя. Інститут інноваційних технологій і змісту освіти Міністерства освіти і науки України, Академія міжнародного співробітництва з креактивної педагогіки. Київ - Вінниця, 2010. С. 159-164.

7. Красільнікова О. В. Компетентнісний підхід як основа філософії освіти. Вісник Київського національного торговельноекономічного університету. 2018. № 1. C. 147-156. URL: http://nbuv.gov.ua/UJRN/Vknteu_2018_1_14 (дата звернення: 12.01.2020)

8. Мартинюк Т. С. Методика реалізації діяльнісного підходу у процесі навчання географії України учнів 8-9 класів : дис. ... канд. пед. наук : 13.00.02. Київ, 2016. 222 с.

9. Рудніцька К. В. Сутність понять «компетентнісний підхід», «компетентність», «компетенція», «професійна компетентність» у світлі сучасної освітньої парадигми. Науковий вісник Ужгородського університету. Серія: «Педагогіка. Соиіальна робота». 2016. Вип. 1 (38), с. 241-244.

10. Часнікова О. В. Компетентнісний підхід в освіті як основа її реформування. Народна освіта. Електронне наукове фахове видання. Розділ «Педагогічна наука». 2014. Вип. № 3 (24). URL: www.narodnaosvita.kiev.ua (дата звернення: 12.01.2020).

11. Яценко С. Л. Особистісно орієнтоване навчання: теоретичний та прикладний аспекти. Проблеми освіти: Наук-метод. зб. / Інститут інноваційних технологій і змісту освіти МОН Украӥни. Київ, 2015. Вип. 85. С. 231-237.

\section{References:}

1. Ball, G.A. (1990). Teoriya uchebnyih zadach: Psihologo-pedagogicheskiy aspect [Learning theory: Psychological pedagogical aspect] Moskva: Pedagogika [in Russian].

2. Burkova, L.V. (2015). Zadachnyi pidkhid u pidhotovtsi fakhivtsiv sotsionomichnykh profesii: typy zadach ta osoblyvosti yikh rozviazannia [The task approach in training specialists of socio-economic professions: types of tasks and peculiarities of their solving]. Visnyk Kyivskoho natsionalnoho universytetu imeni Tarasa Shevchenka. Pedahohika - Taras Shevchenko national university newsletter. Pedagogy, 2, 11-16. Retrieved from http://nbuv.gov.ua/UJRN/vknutshp_2015_2_4 [in Ukrainian].

3. Vitvytska, S.S. \& Dubaseniuk, O.A. (Ed). (2012). Osobystisno oriientovane vykhovannia studentiv $\bar{u}$ vyshchykh navchalnykh zakladakh osvity. [Personally oriented education of students in higher educational establishments]. Profesiina pedahohichna osvita: osobystisno oriientovanyi pidkhid - Professionally pedagogical education: personally oriented approach. Zhytomyr: Vyd-vo ZhSU im. I. Franka, 50-78 [in Ukrainian].

4. Vyigotskiy, L.S. \& Davyidova, V.V. (Ed). (1982). Sobranie sochineniy. Problemyi obschey psihologii [Collected works. Problems of general psycology]. (Vols. 1-6). Moskva: Pedagogika [in Russian].

5. Dubaseniuk, O. A. (2019) Metodolohiia ta metody naukovo-pedahohichnoho doslidzhennia [Methodology and methods of scientific pedagogical research]. Zhytomyr: FO-P Levkovets N.M. [in Ukrainian].

6. Dubaseniuk, O.A. (2010). Realizatsiia zadachnoho pidkhodu u profesiinii pidhotovtsi maibutnoho vchytelia. [Realization of the task approach in professional training of a future teacher]. Instytut innovatsiinykh tekhnolohii $i$ zmistu osvity Ministerstva osvity i nauky Ukrainy. Akademiia mizhnarodnoho spivrobitnytstva z kreaktyvnoi pedahohiky - Innovation technology and education content institute of the Ukrainian education and science ministry. Academy of the international cooperation on creative pedagogy, (pp. 159-164). Kyiv - Vinnytsia. [in Ukrainian].

7. Krasilnikova, O.V. (2018) Kompetentnisnyi pidkhid yak osnova filosofii osvity [The competence approach as the basis of education philosophy]. Visnyk Kyivskoho natsionalnoho torhovelno-ekonomichnoho universytetu - Kyiv national commercial and economical university newsletter, 1, 147-156. Retrieved from http://nbuv.gov.ua/UJRN/Vknteu 2018 _ 14 [in Ukrainian].

8. Martyniuk, T.S. (2016). Metodyka realizatsii diialnisnoho pidkhodu u protsesi navchannia heohrafii Ukrainy uchniv 8-9 klasiv [Methodology of realizing the activity approach during teaching Geography to pupils of 8-9 forms]. Candidate's thesis. Kyiv : NAPS [in Ukrainian].

9. Rudnitska, K.V. (2016). Sutnist poniat «kompetentnisnyi pidkhid», «kompetentnist», «kompetentsiia», «profesiina kompetentnist» u svitli suchasnoi osvitnoi paradyhmy [The essence of the concept "competence approach", "competence", "professional competence" in the light of the modern educational paradigm]. Naukovyi visnyk Uzhhorodskoho universytetu. Seriia: "Pedahohika. Sotsialna robota» - Uzhhorod university scientific newsletter. Ser. "Pedagogy. Social work", 1 (38), 241-244 [in Ukrainian].

10. Chasnikova, O.V. (2014) Kompetentnisnyi pidkhid v osviti yak osnova yii reformuvannia [Competence approach as the basis for reforms]. Narodna osvita. Elektronne naukove fakhove vydannia. Rozdil «Pedahohichna nauka»-Public education. Electronic professional edition. Part "Pedagogical science", 3 (24). Retrieved from www.narodnaosvita.kiev.ua [in Ukrainian].

11. Iatsenko, S.L. (2015) Osobystisno oriientovane navchannia: teoretychnyi ta prykladnyi aspekty [Personally oriented teaching: theoretical and practical aspects]. Problemy osvity-Problems of education. Kyiv : MON Ukrainy, issue 85, 231-237 [in Ukrainian].

\footnotetext{
Hyliarska O. I. Methodological approaches to the formation of professionally oriented rhetorical competence of future teachers in pedagogical colleges and ways of their realization

The article examines methodological approaches to the formation of professionally oriented rhetorical competence of future teachers in the educational process in pedagogical colleges. Scientific sources have been reviewed on the analysis of methodological approaches such as competence, personality-oriented, activity-based and task-oriented. It has been found that it
} 
is the most logical to consider the formation of professionally oriented rhetorical competence from the standpoint of these approaches.

It is determined that according to the competence approach the learning process acquires a developmental character and contains knowledge, skills, attitudes and experience of pedagogical activity. It is proved that a person-centered approach is aimed at recognizing the value, uniqueness of the future teacher's personality, his right to free development and displaying his abilities in pedagogical activity, forming his own style in communication. It is noted that the activity approach is implemented through purposeful learning and the upbringing process that results from the use of persuasive words. The attention is drawn to the fact that the task-oriented approach of the formation of professionally oriented rhetorical competence in future teachers is the process of forming the ability to solve professional and communicative tasks.

The importance of rhetorical competence for the teacher is considered greatly significant, as it has a professional focus and is used primarily to solve educational problems. It is proved that the professionally oriented rhetorical competence of the future teacher is connected with the mastery of pedagogical influence of the word, with the effectiveness of technology of developmental cultural education and education through effective, convincing speech. The prospects for further research in this area are identified.

Key words: methodological approaches, vocationally oriented rhetorical competence, future teachers, competence approach, personality-oriented approach, activity approach, task-oriented approach, pedagogical colleges.

\author{
УДК 378.6:624(430) \\ DOI https://doi.org/10.31392/NPU-nc.series5.2020.72-1.27
}

Григор'єва В. А.

\title{
СИСТЕМА ПІДГОТОВКИ ІНЖЕНЕРІВ-БУДІВЕЛЬНИКІВ У ТЕХНІЧНИХ УНІВЕРСИТЕТАХ НІМЕЧЧИНИ
}

Розглянуто систему підготовки інженерів-будівельників у технічних університетах Німеччини та зміни, які відбулися в ії структурі в контексті Болонського прочесу. Зосереджено увагу на одному з аспектів реформування закладів вищої освіти - упровадження дворівневої системи навчання зі здобуттям освітніх ступенів бакалавра й магістра. Охарактеризовано особливості підготовки фахівиів із будівництва за першим і другим рівнями вищої освіти в технічних університетах: умови вступу до бакалавріату (наявність Abitur - атестата зрілості, який можна отримати після навчання в гімназї або в загальній школі за програмою гімназії; обов'язкове проходження дво-, тримісячноі попередньої практики, метою якої є отримання інформаиї про перебіг основних робочих процесів, пов'язаних із майбутньою професією на будівниитві); допуском до навчання за магістерською програмою є ступінь бакалавра, однак університети мають право самостійно визначати умови, за якими вони набирають студентів; види магістратури з різними умовами вступу (послідовна, яка починається одразу після бакалавріату, та спрямована на підвищення кваліфікаиії, щзо не залежить від ступеня бакалавра, а передбачає наявність досвіду професійної діяльності); відсутність практичної підготовки за магістерською програмою через короткий термін навчання; присвоєння кваліфікаціі бакалавра/магістра інженерії (Bachelor of Engineering / Master of Engineering) та бакалавра/магістра наук (Bachelor of Science / Master of Science), яке залежить від профілю освітніх програм (більш орієнтованих на проведення досліджень або більш орієнтованих на практичну діяльність); компетентності випускників бакалаврських і магістерських програм за спеціальністю «Будівництво»; тривалість написання випускових робіт - від 5 до 10 тижнів за бакалаврським рівнем і від 12 до 23 тижнів за магістерським тощо.

Ключові слова: Німеччина, вища освіта, технічний університет, інженер-будівельник, Болонський процес, бакалавріат, магістратура.

Будівництво як галузь промисловості посідає в Німеччині ключову позицію серед усіх секторів економіки, створює передумови для розвитку злагодженого функціонального суспільства та загального економічного зростання. Саме тому країна докладає чимало зусиль для створення належних умов для забезпечення будівельної галузі висококваліфікованими фахівцями. Уже протягом багатьох років інженерна освіта Німеччини вважається однією з найкращих у світі: технічні університети стабільно посідають найвищі щаблі у світових рейтингах; Німеччина належить до п'яти найпопулярніших країн для іноземних студентів; система технічної освіти була і залишається загальноприйнятим еталоном підготовки спеціалістів.

Підготовка майбутніх інженерів у Німеччині, зокрема інженерів-будівельників, є актуальною науковою проблемою, що відображається в працях дослідників багатьох країн світу: Є.-М. Гайнендірк, Т. Голуб, О. Горшкової, А. Губауера, Е. Грос, Г. Дудар, О. Дудар, В. Зобека, Й. Ланге, А. Пономарьова, І. Чадежа, Г. Юнге та ін. У своїх працях науковці розглянули застосування інноваційних методів навчання, науководослідницьку роботу студентів технічних спеціальностей, особливості професійної підготовки майбутніх інженерів-будівельників у технічних університетах тощо. Проте не було здійснено узагальненого опису сучасної системи підготовки інженерів-будівельників у Німеччині, що, на нашу думку, є на сьогодні актуальним для сучасних науковців і практиків. 